\title{
KESIAPAN MEMASUKI SEKOLAH DASAR PADA ANAK DI TKIT ATTAQWA GUMAWANG TAHUN 2016
}

\author{
Eka Marwati', Sholeh Hasan², Dwi Andriani ${ }^{3}$
}

\begin{abstract}
Education becomes an essential thing in human development and nation progress. Phenomenon of elementary school test that should become an interesting thing, is a new scourge for students and parents. Competency demand that should be qualified by new student rises without noticing student readiness for attending primary school. This research is aimed to know readiness for attending school on TKIT students Attaqwa Gumawang. The research is applied on 59 students of TKIT Attaqwa Gumawang. The data is obtained by 10 sub tests that reveal development aspects of school age-children. The result data is analyzed by using analysis technique of descriptive quantitative. The research result shows all aspects that are required for student readiness for attending primary school are generally mature. Qualitatively, some aspects for attending primary school that related with cognitive aspect are observation, ability to distinguish, understanding about large, quantity and comparison, sharpness of observation, critical observation, concentration, memory and understanding story are some aspects that have already reached to maturity level optimally. Besides, the maturity level some aspects that related with fine and gross motoric ability, assessment aspect toward situation and personal picture are not optimal yet.
\end{abstract}

Keywords: Kindergarten, Primary School, Readiness.

\section{PENDAHULUAN}

Pendidikan tentunya menjadi hal yang penting dalam perkembangan manusia dan kemajuan suatu bangsa. Oleh karenanya berbagai upaya dilakukan baik oleh pemerintah maupun pelaksana pendidikan untuk mengoptimalkan tercapainya pendidikan yang sesuai dengan harapan yang dicita-citakan. Salah satu upaya yang dilakukan pemerintah adalah dengan mewajibkan pendidikan formal 9 tahun. Sesuai dengan Undang-Undang Nomor 20 Tahun 2003, tentang Sistem Pendidikan Nasional pasal 6 ayat (I) dikemukakan "Setiap warga negara yang berusia tujuh sampai lima belas tahun wajib mengikuti pendidikan dasar". Pendidikan formal yang diwajibkan ini dimulai dari jenjang sekolah dasar atau SD hingga sekolah menengah atas atau biasa disebut SMA.

Secara umum perkembangan anak normal pada usia tujuh tahun sudah siap untuk belajar dan telah mencapai masa peka untuk belajar ketrampilan akademik

\footnotetext{
${ }^{1}$ STKIP Nurul Huda Sukaraja (stkipnurulhuda.ac.id), OKU Timur, Sumatera Selatan; eka_marwati86@yahoo.co.id.

${ }^{2}$ STKIP Nurul Huda Sukaraja, OKU Timur, Sumatera Selatan.

${ }^{3}$ STKIP Nurul Huda Sukaraja, OKU Timur, Sumatera Selatan.
} 
(Supartini, 2006). Namun hal ini berbeda dengan hasil observasi di lapangan yang menunjukkan menunjukkan bahwa memasuki pendidikan formal pertama atau sekolah dasar, masyarakat atau bahkan penyedia pendidikan beranggapan bahwa anak sudah harus mampu menguasai calistung (membaca, menulis dan menghitung) bukan lagi memulai proses belajar. Tidak sedikit sekolah yang menerima murid dengan melakukan tes calistung. Hal ini juga berbanding lurus dengan anggapan orang tua yang menilai keberhasilan di sekolah TK adalah mempersiapkan anak untuk mampu calistung sebelum masuk sekolah dasar. Masalah lain timbul ketika ada siswa yang belum cukup usia ingin masuk sekolah dasar.

Kasus di atas adalah sebagaian kecil masalah yang dihadapi dunia pendidikan sebelum memulai kegiatan belajar. Pada saat belajar tentu akan muncul masalah baru, diantarannya beberapa anak masih harus ditunggu oleh orang tua di dalam kelas. Selain itu ada beberapa anak yang mampu berhitung namun kemampuan motoriknya masih sangat kurang dan membutuhkan bantuan dalam menulis. Tak sedikit dijumpai, anak yang baru masuk sekolah mengompol di celana karena belum mampu mengkomunikasikan dengan guru baru. Bahkan, lebih menggelikan manakala anak masih ingin tetap bersekolah di TK B, padahal secara usia dan perkembangan sudah saatnya masuk sekolah dasar.

Senada diungkapkan oleh Sadrina (2015) bahwa beberapa masalah anak usia SD yang ia tangani adalah masalah kemandirian, konsentrasi, masalah relasi sosial, masalah motivasi, prestasi belajar rendah, tulisan besar dan kasar, keliru menulis huruf dan angka, belum lancar membaca, dll. Disamping itu terdapat pula masalh yang terkait dengan pola pengasuhan diantaranya: mudah marah, memukul dan menyakiti teman.

Masalah ini timbul karena ketidakmatangan anak saat masuk SD yang tidak terdeteksi dak akhirnya menjadi bertumpuk dan berlarut-larut. Lebih lanjut Sadrina (20I5) menjelaskan dampak yang ditimbulkan tidak hanya terganggunya prestasi akademik namun juga mempengaruhi relasi sosial anak dengan teman serta menimbulkan kekecewaan pada orang tua yang merasa sudah mengupayakan berbagai hal untuk pendidikan anak, namun hasilnya tidak memuaskan. 
Masuk sekolah dasar merupakan pengalaman baru bagi sebagian besar anak-anak. Walaupun mungkin sebelumnya mereka sudah menjalani masa pra sekolah seperti PAUD, Play Group, Day Care, dan TK. Hal ini menimbulkan seringkali kemudian anak mengalami masalah di hari-hari pertama berada di lingkungan sekolah dasar. Karena itu menurut Ambarwati (20I6), penting bagi orang tua untuk mengetahui apakah putra-putrinya telah memiliki kesiapan masuk sekolah dasar.

Uraian di atas menunjukkan dua hal yang perlu diperhatikan sebelum anak masuk sekolah, yaitu kematangan masuk sekolah dan kesiapan masuk sekolah. Kematangan mengacu pada pertumbuhan biologis yang perlu dicapai sebelum masuk sekolah, misalnya kematangan otak untuk memahami konsep membaca, menulis, menghitung dan memahami sudut pandang orang lain. Kematangan tidak dapat dipercepat, karena sudah berproses sedemikian rupa secara alami. Biasanya anak matang secara biologis untuk memasuki sekolah dasar adalah pada usia 6 tahun. Kematangan secara biologis, selain ditunggu juga perlu didukung stimulasi. Stimulasi yang disajikan pada anak akhirnya mewujudkan sebuah kesiapan.

Kesiapan anak masuk sekolah dasar akan berbeda satu dengan yang lain. $\mathrm{Hal}$ ini tergantung pada stimulasi yang diberikan dan kematangan yang dicapai. Capaian kematangan yang perlu diperhatikan meliputi aspek-aspek perkembangan anak, yakni fisik dan motorik, sosial, emosi, dan kognitif (Jannah, 20I5). Secara motorik anak harus sudah mampu duduk dalam jangka waktu lama, terampil menggunakan tangan untuk kegiatan menulis dan lainnya. Secara kognitif kematangan anak terlihat dari ketajaman pengamatannya, kemampuan membedakan diantara persamaan, membedakan figure dan ground. Secara sosial dan emosi anak merasa nyaman terpisah dari lingkungan rumah, orang tua dan menerima otoritas dari guru serta bergaul dengan teman sebaya.

Untuk mengetahui sejauh mana capaian kematangan anak untuk siap masuk sekolah, perlu dilakukan pengukuran kesiapan masuk sekolah dasar. Sebagaimana telah berkembangnya NST (Nijmeegse Schoolbekwaamheid Test) sebagai tes yang lazim digunakan untuk mengukur kesiapan anak sekolah. Melalui NST akan tergambar kematangan anak dalam sisi kognitif, motorik dan sosial emosinya (Supartini, 2006). Hal inilah yang mendasari tujuan peneliti untuk mengetahui bagaimana kesiapan serta melihat kematangan tiap aspek masuk sekolah dasar siswa TKIT Attaqwa Gumawang. 
Penelitian ini diharapkan dapat bermanfaat bagi keilmuan agar dapat memberikan tambahan informasi tentang kesiapan masuk sekolah dasar siswa TKIT Attaqwa Gumawang. Untuk sekolah agar dapat dijadikan sebagai tambahan informasi sebagai bahan evaluasi kurikulum pendidikan, serta bagi siswa dapat mengetahui gambaran kesiapan siswa sebelum memasuki sekolah dasar.

Hal yang perlu diperhatikan adalah adanya dua konsep yang berbeda antara dua konsep istilah "kesiapan untuk belajar", dengan "kesiapan untuk sekolah". Kesiapan untuk belajar secara umum adalah tingkat perkembangan (pada berbagai tingkat usia) untuk mencapai kesiapan untuk mempelajari materi pelajaran secara spesifik. Kondisi yang sebatas siap untuk belajar belum tentu menjadi jaminan untuk mencapai kesuksesan di sekolah. Konsep dari kesiapan untuk sekolah adalah termasuk didalamnya kesiapan untuk belajar didasarkan pada standar tingkat perkembangan fisik, kognitif dan sosial yang memungkinkan anak untuk memenuhi tuntutan dan menjalani kurikulum yang telah ditentukan (Rachmawati \& Damayanti, 2016).

Mengingat pentingnya "kesiapan sekolah" sebagai dasar kemampuan untuk mengikuti berbagai tuntutan kegiatan dan kurikulum sekolah dasar, maka telah berkembang suatu instrumen untuk mengukur kesiapan sekolah yang diukur melalui kematangan anak pada berbagai aspek perkembangan. Tes yang paling sering digunakan adalah NST (Nijmeegse Schoolbekwaamheids Test). Tes ini merupakan alat ukur untuk mengetahui kematangan aspek-aspek yang menunjang kesiapan anak masuk Sekolah Dasar, yaitu yang meliputi kematangan dari aspek kognitif, motorik, dan juga sosial-emosi.

Aspek kognitif yang dimaksud dalam kesiapan mengikuti pendidikan sekolah dasar tidak hanya sebatas tingkat kecerdasan. Namun juga dengan memperhatikan kematangan dari aspek-aspek kognitifnya seperti ketajaman pengamatan, kemampuan persamanaan-perbedaan, juga pemisahan figure dan ground yang menjadi dasar anak untuk melakukan seleksi dan memfokuskan perhatian. Aspek kognitif tersebut menjadi dasar bagi anak untuk memenuhi tuntutan pada berbagai bidang pelajaran, baik itu membaca, berhitung dan juga ketajaman dalam identifikasi dan mengkritisi suatu masalah.

Kematangan di bidang fisik, terutama motorik, menjadi modal bagi anak untuk mampu melakukan kegiatan di SD mulai dari tuntutan untuk mampu 
duduk dalam jangka waktu yang cukup lama, kemampuan menulis, menggambar, dll. Lebih lanjut lagi kematangan motorik menjadi dasar kenyamanan fisik anak yang pada akhirnya membantunya untuk dapat lebih mengendalikan perilaku, dan memfokuskan kegiatan pada satu tugas hingga tuntas (Yusuf \& Sugandhi, 20I2).

Kematangan pada aspek emosi dan sosial memungkinkan anak untuk secara nyaman 'terpisah' dari lingkungan rumah, terutama orang tua, dan mulai memperluas lingkup sosial pada konteks pertemanan, baik dengan sebaya, dan juga dengan orang dewasa lain, dalam hal ini guru. Kondisi ini juga menjadi dasar untuk mencapai kemandirian dalam penyelesaian tugas. Bahkan lebih lanjut lagi dapat memungkinkan anak untuk menjadi individu yang berani tampil dan mampu secara asertif menyatakan pendapat. Kematangan pada aspek ini juga memungkinkan anak untuk mengembangkan kepekaan dan rasa kebersamaan dengan orang lain (Rachmawati dan Damayanti, 2016).

Hasil penelitian Sulistiyaningsih (2005) menyatakan bahwa kesiapan bersekolah menjadi penting artinya karena anak yang telah memiliki kesiapan untuk bersekolah akan memperoleh keuntungan dan kemajuan dalam perkembangan selanjutnya. Sementara itu anak yang tidak memiliki kesiapan, justru akan frustrasi bila ditempatkan di lingkungan akademis. Berbagai bentuk perilaku sebagai cerminan frustrasi ini diantaranya adalah menarik diri, berlaku acuh tak acuh, menunjukkan gejala-gejala fisik, atau kesulitan menyelesaikan tugasnya di sekolah.

Terkait dengan kesiapan sekolah, Hurlock (Sulistiyaningsih, 2005) menyatakan bahwa kesiapan bersekolah terdiri dari kesiapan secara fisik dan psikologis, yang meliputi kesiapan emosi, sosial dan intelektual. Seorang anak dikatakan telah memiliki kesiapan fisik bila perkembangan motoriknya sudah matang, terutama koordinasi antara mata dengan tangan (visio[motorik) berkembang baik. Kesiapan emosional sudah dicapai apabila anak secara emosional dapat cukup mandiri lepas dari bantuan dan bimbingan orang dewasa, tidak mengalami kesulitan untuk berpisah dalam waktu tertentu dengan orangtuanya, dapat menerima dan mengerti setiap tuntutan di sekolah, serta dapat mengontrol emosinya seperti rasa marah, takut, dan iri. Selain itu anak harus sudah dapat bekerjasama, saling menolong, menunggu giliran untuk suatu tugas dan sebagainya. Anak yang telah siap secara sosial akan mudah menyesuaikan diri dengan harapan-harapan dan aturan-aturan di sekolah. 
Kustimah (2008) menyatakan beberapa faktor dalam kesiapan sekolah anak meliputi: I) kesehatan fisik; 2) usia; 3) tingkat kecerdasan; 4) stimulasi tepat; dan 5) motivasi.

Pertama, Kesehatan Fisik. Kesehatan yang baik dengan asupan gizi yang seimbang sangat dibutuhkan untuk dapat menunjang kesiapan masuk sekolah. Anak yang sehat akan lebih mudah mencerna pengetahuan yang diajarkan serta bersosialisasi dengan lebih baik, tampil gesit dan bersemangat, baik dalam menerima informasi maupun dalam membina hubungan sosial dengan guru serta teman-temannya.

Kedua, Usia. Beberapa ahli mengatakan bahwa faktor usia sangatlah penting untuk menentukan kesiapan anak masuk sekolah dasar. Menurut Janke, Comenius, Buhler dan Hetzer dalam buku Nijmeegse Schoolbekwaamheids Test menganggap usia 6 tahun sebagai usia yang cukup matang untuk sekolah. Pada usia ini umumnya anak telah memiliki perbendaharaan kata yang cukup banyak, memiliki kemampuan membayangkan seperti anak-anak seusianya, dapat mengemukakan secara verbal ide-ide dan pikiran-pikirannya serta organ-organ indra dan motorik telah terkoordinasi dengan baik.

Ketiga, Tingkat Kecerdasan. Kecerdasan/inteligensi merupakan kemampuan seorang anak dalam memahami instruksi verbal teoritis dan menyelesaikan tugas-tugas konkrit praktis dibandingkan dengan anak-anak seusianya. Anak-anak dengan tingkat kecerdasan yang berfungsi pada tahap rata-rata akan menyelesaikan tugas-tugas tersebut secepat anak-anak seusianya. Adapun anak-anak yang memiliki tingkat kecerdasan tinggi akan menyelesaikan tugas-tugas tersebut secara lebih cepat dan sebaliknya anak-anak yang memiliki tingkat kecerdasan rendah akan melaksanakannya dengan lebih lambat. Dengan demikian untuk memasuki dunia sekolah yang memiliki program pembelajaran untuk usia tertentu, maka setidaknya seorang anak memiliki tingkat kecerdasan yang berfungsi pada tahap rata-rata.

Keempat, Stimulasi Tepat. Faktor lingkungan terdekat dengan anak sangat berperan dalam menunjang kesiapan anak untuk memasuki sekolah dasar, sehingga potensi perkembangan anak yang dimiliki anak dapat berkembang secara optimal. Orangtua dan guru memegang peranan yang sangat penting dalam mengembangkan aspek-aspek yang sangat menunjang kesiapan anak untuk sekolah meliputi semua perkembangan baik perkembangan motorik 
kasar dan halus, perkembangan bahasa, perkembangan sosial, perkembangan kognisi dan perkembangan emosi anak.

Kelima, Motivasi. Anak yang merasa bahagia biasanya memiliki motivasi baik untuk melakukan sesuatu, serta umumnya melakukan kegiatan didasari oleh tujuan tertentu.

Dari uraian di atas dapat disimpulkan bahwa kesiapan masuk sekolah dasar merupakan kondisi fisik dan psikologis yakni perkembangan fisik, kognitif dan sosial emosi yang memungkinkan anak untuk untuk mampu belajar, berkegiatan dalam memenuhi tuntutan dan menjalani kurikulum yang telah ditentukan sekolah.

Nijmeegse Schoolbekwaamheids Test (NST) disusun oleh F. J. Mönks, H. Rost, dan N. H. Coffie, merupakan alat ukur untuk mengetahui kematangan aspek-aspek yang menunjang kesiapan anak masuk Sekolah Dasar, yang meliputi aspek kognitif, motorik, dan juga sosial-emosi (Rachmawati \& Damayanti, 2016). Tes ini terdiri atas 10 subtes, dengan gambaran tes yang berisi gambar-gambar atau melengkapi gambar sekaligus jawabannya, yang masing-masing mengungkap kemampuan yang berbeda, yaitu:

I) Subtes I: Pengamatan bentuk dan kemampuan membedakan;

2) Subtes 2: Motorik halus;

3) Subtes 3: Pengertian tentang besar, jumlah, dan perbandingan;

4) Subtes 4: Pengamatan tajam;

5) Subtes 5: Kemampuan berpikir kritis;

6) Subtes 6: Konsentrasi;

7) Subtes 7: Ingatan;

8) Subtes 8: Pengertian objek dan penilaian situasi;

9) Subtes 9: Menirukan cerita;

10) Subtes 10: Menggambar orang.

Lebih lanjut Supartini (2006) menjelaskan bahwa untuk mengetahui seorang anak siap sekolah, anak diminta mengerjakan keseluruhan tes, kemudian skoring, hasilnya dikonsultasikan dengan tabel sehingga dapat diketahui apakah anak sudah siap sekolah atau belum. Selain itu dapat dibuat 
profil kemampuan anak dari 10 aspek yang diungkap oleh masing-masing sub tes tersenut, untuk menggambarkan kemampuan anak.

Dapat disimpulkan bahwa kesiapan anak sekolah terdiri dari beberapa aspek, baik fisik maupun psikologis dan salah satu alat tes untuk mengukur kesiapan sekolah adalah Nijmeegse Schoolbekwaamheids Test (NST) yang mengukur aspek-aspek kognitif, motorik halus dan motorik kasar, penilaian sosial, serta emosional.

\section{METODE}

Jenis penelitian ini adalah penelitian kuantitatif. Analisis terhadap data akan dilakukan secara kuantitatif dengan teknik statistik sederhana. Hasil yang akan diperoleh merupakan gambaran deskripsi mengenai kseiapan anak masuk Sekolah Dasar ditinjau dari hasil tes NST.

Desain penelitian kuantitatif ini dibagi dalam empat tahap, yaitu:

I) Perencanaan. Kegiatan yang dilakukan dalam tahap ini adalah sebagai berikut: analisis masalah dilapangan, penyusunan rancangan penelitian, penetapan tempat penelitian, dan penentuan instrumen penelitian.

2) Pelaksanaan Pada tahap ini peneliti sebagai pelaksana penelitian melakukan pencarian data dengan bekerjasama instansi yang diberikan kewenangan untuk melakukan tes pada tempat penelitian.

3) Analisis Data. Analisis data dilakukan setelah peneliti mendapat data hasil tes NST yang dilakukan di tempat penelitian menggunakan teknik statistik sederhana.

4) Evaluasi. Semua data yang telah dianalisis kemudian dievalusi sehingga diketahui kesiapan siswa masuk sekolah dasar.

Tempat penelitian adalah TKIT Attaqwa Gumawang, yang beralamat di Desa Gumawang, Kecamatan Belitang, Kabupaten OKU Timur, Sumatera Selatan. Waktu pelaksanaan pada tanggal 3I Mei 2016. Pengambilan subyek penelitian dengan menggunakan sampel jenuh dimana semua siswa menjadi subyek penelitian. Subyek penelitian ini adalah siswa TKIT Attaqwa Gumawang yang akan masuk sekolah dasar di tahun ajaran 2016/2017 dengan jumlah 59 siswa. 
Data pada penelitian ini diperoleh dari tes yakni menggunakan NST sebagai instrumennya. NST digunakan untuk melihat kesiapan masuk sekolah dasar yang terdiri dari 10 sub tes dan 8 tes setiap subtesnya.

Analisis kuantitatif yang digunakan dalam penelitian ini berupa analisis statistik deskriptif, yakni statistik yang digunakan dalam menganalisis data dengan cara mendeskripsikan atau menggambarkan data yang telah terkumpul sebagaimana adanya tanpa bermaksud membuat kesimpulan yang berlaku untuk umum atau generalisasi. Analisis ini berupa akumulasi data dasar dalam bentuk deskripsi yang tidak mencari atau menerangkan saling hungungan, menguji hipotesis, membuat ramalan atau penalaran kesimpulan (Suryabrata, 1994).

Teknik analisis statistik deskriptif yang digunakan, seperti: I) Penyajian data dalam bentuk tabel atau distribusi frekuensi dan tabulasi silang. Dengan analisis ini akan diketahui kecendrungan hasil temuan penelitian, apakah masuk dalam kategori rendah, sedang atau tinggi; 2) Penyajian data dalam bentuk visual, seperti histogram, poligon, ogive, diagram batang, diagram lingkaran, diagram pastel, dan diagram lambang; 3) Penghitungan ukuran tendensi sentral (mean, median, modus); 4) Penghitungan ukuran letak (kuartil, desil dan presentil); 5) Penghitungan ukuran penyebaran (standar deviasi, varians, range, deviasi kuartil, mean deviasi dan sebagainya) (Sudjana, 1994).

\section{DISKUSI}

Proses pelaksanaan penelitian diawali dari kebutuhan siswa TKIT Attaqwa yang hendak masuk Sekolah Dasar membutuhkan evaluasi terkait dengan kesiapan untuk masuk sekolah. Kebutuhan evaluasi ini dapat dipenuhi dengan dilakukannya tes kesiapan masuk sekolah dasar yakni menggunakan tes NST. Instrumen tes NST dimiliki oleh poli konseling RSUD OKU Timur yang memberikan pelayanan psikologi bagi masyarakat.

Pada pelaksanaan, maka dari sekolah mengirimkan surat untuk dilakukan tes kesiapan masuk SD kepada Poli Konseling. Kemudian dilakukan tindak lanjut berkenaan dengan jumlah siswa, tanggal dan tempat pelaksanaan. Siswa yang ikut serta dalam tes berjumlah 59 siswa yang terbagi ke dalam 3 kelas. Pelakasanaan dilakukan dalam satu hari kerja dan dilakukan di sekolah TKIT Attaqwa Gumawang. Pada saat pelaksaanan tes, siswa didampingi oleh guru pendamping dan tes dilakukan oleh tim psikologi sebanyak 4 orang. 
Tahapan pelaksaan tes dimulai dengan perkenalan, ice breaking dengan bernyanyi dan bertanya, dilanjutkan dengan pembagian lembar tes dan alat tulis pensil. Sebelum tes dimulai, terlebih dahulu untuk mengisi lembar identitas berupa nama siswa yang mengikuti tes. Tes dilaksanakan dalam sepuluh tahapan subtes, adapun kesepuluh tahapan subtes tersebut tampak pada Tabel I.

Tabel I. Sepuluh Tahapan Subtes

\begin{tabular}{|c|c|c|}
\hline Tes & Aspek Yang di Ukur & Materi \\
\hline Subtes I & $\begin{array}{l}\text { Pengamatan bentuk } \\
\text { dan kemampuan } \\
\text { membedakan }\end{array}$ & $\begin{array}{l}\text { Terdiri dari } 8 \text { soal, dalam masing-masing soal } \\
\text { terdapat I gambar (disebelah kiri) yang harus } \\
\text { dicocokkan dengan I gambar dari kelima } \\
\text { gambar pilihan (sebelah kanan) }\end{array}$ \\
\hline Subtes 2 & Motorik halus & $\begin{array}{l}\text { Terdiri dari } 8 \text { soal, masing-masing soal berupa } \\
2 \text { gambar. I gambar lengkap bentuknya, I } \\
\text { gambar lain tidak lengkap bentuknya. }\end{array}$ \\
\hline Subtes 3 & $\begin{array}{l}\text { Pengertian tentang } \\
\text { besar, jumlah dan } \\
\text { perbandingan }\end{array}$ & $\begin{array}{l}\text { Terdiri dari } 8 \text { soal, terdapat benda/ orang yang } \\
\text { berderet. }\end{array}$ \\
\hline Subtes 4 & $\begin{array}{l}\text { Ketajaman } \\
\text { pengamatan }\end{array}$ & $\begin{array}{l}\text { Terdiri dari } 8 \text { soal. Setiap soal terdiri dari } \\
\text { bentuk binatang yang tersamar diantara bentuk } \\
\text { lainnya. }\end{array}$ \\
\hline Subtes 5 & Pengamatan kritis & $\begin{array}{l}\text { Terdiri dari } 8 \text { soal. Masing-masing soal berupa } \\
\text { gambar yang tidak lengkap bentuknya. }\end{array}$ \\
\hline Subtes 6 & Konsentrasi & $\begin{array}{l}\text { Terdiri dari I } 2 \text { baris yang berisikan berbagai } \\
\text { bentuk. Terdapat } 8 \text { bentuk yang sesuai dengan } \\
\text { bentuk yang diminta untuk ditemukan. }\end{array}$ \\
\hline Subtes 7 & Daya ingat & $\begin{array}{l}\text { Terdiri dari I } 6 \text { gambar, } 8 \text { diantaranya adalah } \\
\text { gambar yang pernah diperlihatkan sebelumnya. }\end{array}$ \\
\hline Subtes 8 & $\begin{array}{l}\text { Pengertian tentang } \\
\text { obyek dan penilaian } \\
\text { terhadap situasi }\end{array}$ & $\begin{array}{l}\text { Terdiri dari } 8 \text { soal. Disetiap soal terdapat } 4 \\
\text { pilihan gambar/ situasi. Satu gambar/ situasi } \\
\text { yang merupakan pilihan yang dimaksud. }\end{array}$ \\
\hline Subtes 9 & Memahami cerita & $\begin{array}{l}\text { Terdiri dari I5 pilihan gambar. } 8 \text { diantaranya } \\
\text { merupakan gambar yang sesuai dengan cerita. }\end{array}$ \\
\hline Subtes 10 & Gambar orang & $\begin{array}{l}\text { Halaman kosong untuk anak menggambar } \\
\text { orang sebagus yang ia mampu. }\end{array}$ \\
\hline
\end{tabular}

Setelah tes selesai dilakukan, maka tahap selanjutnya adalah melakukan koreksi terhadap hasil yang telah dikerjakan semua siswa. Setiap jawaban yang benar diberikan nilai I (satu) dan untuk jawaban yang salah tidak diberikan skor. Tes ini terdiri dari 10 subtes, yang setiap subtesnya memiliki skor mainimal 0 (nol) dan skor maksimal 8 (delapan). Hasil setiap subtes yang diperoleh kemudian dipindahkan ke kolom profil. Pada kolom ini terdapat sebaran skor 
disetiap subtesnya yang masuk dalam norma kesiapan. Norma ini yang akan menentukan apakah pada subtes tersebut siswa masuk dalam kategori belum siap, ragu atau siap untuk masuk sekolah. Setelah skor dipindah, maka dilakukan identifikasi kesiapan untuk setiap subtes semua siswa. Setelah diketahui hasil tiap subtes, langkah penelitian selanjutnya melakukan tabulasi data ke dalam tabel. Dalam hal ini dilakukan teknik statistik sederhana untuk mendaptakan gambaran deskriptif mengenai kesiapan siswa TKIT Attaqwa Gumawang masuk Sekolah Dasar.

Perolehan data (sebaran data terlampir) dari hasil tes dimasukkan dalam exel untuk diolah dalam statistik sederhana untuk memperoleh kategori dan jumlah prosentase siswa yang masuk dalam kategori siap, ragu dan belum siap di setiap subtesnya. Hasil yang diperoleh dari setiap subtes yang diukur dalam NST disajikan dalam Tabel 2.

Tabel 2. Nilai hasil tes kesiapan masuk sekolah dasar menggunakan NST

\begin{tabular}{lccc}
\hline \multirow{2}{*}{ Subtes } & \multicolumn{3}{c}{ Kategori } \\
\cline { 2 - 4 } & Belum Siap & Ragu & Siap \\
\hline Subtes I & 0 & 1 & 58 \\
\hline Subtes 2 & 4 & 2 & 53 \\
\hline Subtes 3 & 3 & 4 & 52 \\
\hline Subtes 4 & 4 & 4 & 51 \\
\hline Subtes 5 & 1 & 1 & 75 \\
\hline Subtes 6 & 1 & 7 & 51 \\
\hline Subtes 7 & 0 & 16 & 43 \\
\hline Subtes 8 & 5 & 8 & 46 \\
\hline Subtes 9 & 2 & 0 & 57 \\
\hline Subtes 10 & 31 & 15 & 13 \\
\hline
\end{tabular}

Pada subtes I yakni pengamatan bentuk dan kemampuan membedakan. Pada subtes ini terdiri dari 8 soal, dalam masing-masing soal terdapat I gambar (disebelah kiri) yang harus dicocokkan dengan I gambar dari kelima gambar pilihan (sebelah kanan). Terlihat bahwa sebanyak $98 \%$ siswa mampu melakukan dengan benar. Kemampuan kognitif yang dimiliki untuk melihat kecocokan gambar dengan instruksi yang dimaksud dapat berjalan dengan baik.

Pada subtes 2 yakni motorik halus dengan terdiri dari 8 soal, masingmasing soal berupa 2 gambar. I gambar lengkap bentuknya, I gambar lain tidak 
lengkap bentuknya. Pada tahap ini sebanyak $90 \%$ siswa dengan motorik halus yang telah siap untuk mampu belajar menulis dan kegiatan motorik lainnya di sekolah.

Subtes 3 yakni pengertian tentang besaran jumlah dan perbandingan yang terdiri dari 8 soal, terdapat benda/ orang yang berderet. Siswa yang telah mampu memahami dan membandingkan besaran serta jumlah suatu benda sebanyak $88 \%$.

Subtes 4 berupa pengamatan tajam. Stimulus yang diberikana adalah mencari binatang yang tersamar dalam bentuk-bentu benda. Kejelian dalam mengamati situasi dan gambar hanya mampu dilakukan oleh $86 \%$ siswa untuk dapat dikatakan siap.

Subtes 5 adalah pengamatan kritis dimana siswa mampu untuk menilai kondisi atau situasi yang dirasa kurang atau belum lengkap. Pada subtes ini sebanyak $96 \%$ siswa sudah mampu melakukannya dengan baik.

Subtes 6 adalah konsentransi, yang mana siswa membutuhkan fokus dengan batasan waktu untuk mencari benda yang sama. Pada hal ini $86 \%$ siswa mampu melakukan, artinya situasi sekitar tidak begitu berpengaruh dalam menggangggu konsentrasi mereka untuk menyelesaikan tugas dengan baik.

Subtes 7 adalah daya ingat. Siswa kembali mengingat stimulus gambar yang telah disajikan sebelumnya. Sebanyak $73 \%$ siswa mampu mengingat dengan baik stimulus yang pernah ia jumpai.

Subtes 8 berupa pengertian tentang objek dan penilaian terhadap situasi. $78 \%$ siswa mampu memahami situasi dan mengerti arti suatu kejadian.

Dilanjutkan dengan subtes 9 adalah kemampuan siswa untuk memahami sebuah cerita. Sebanyak $97 \%$ anak sudah mampu menangkap cerita yang disampaiakan, dalam hal ini penjelasan yang ia terima mampu dituangkan dalam jawaban yang dipilih.

Subtes 10 adalah bagian terakhir dari rangkaian tes NST. Pada bagian ini siswa diminta untuk membuat gambar orang yang menurutnya paling bagus. Pada kemampuan ini hanya $22 \%$ siswa yang mampu menggambar dengan baik, dalam hal ini kemampuan siswa dalam memahami fungsi tubuh dan mengenali diri sudah mampu dilakukan. Siswa mengenali bagian-bagian tubuhnya dengan 
baik selain itu ia mampu menampilkannya menjadi suatu aktivitas atau fungsi keseharian dari masing-masing bagian tubuhnya.

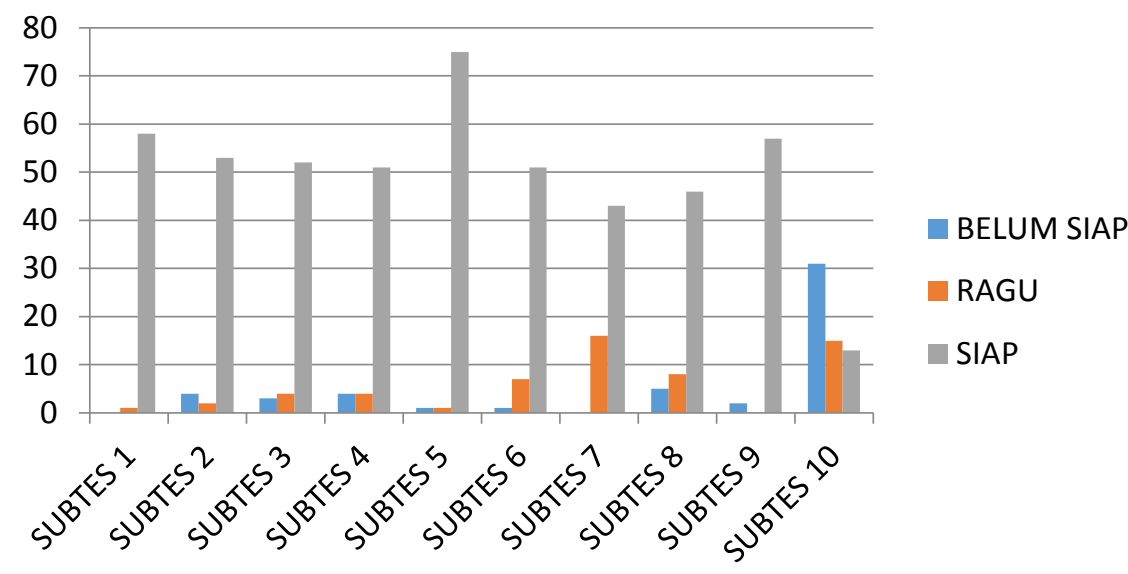

Gambar I. Hasil tes kesiapan masuk sekolah dasar menggunakan NST

Hasil analisis data yang dilakukan menunjukkan hampir seluruh aspek pada umumnya sudah matang, artinya seluruh siswa telah memiliki kesiapan untuk dapat mengikuti proses belajar di Sekolah Dasar. Sebagaimana yang diungkapkan oleh Rachmawati dan Damayanti (2016) bahwa konsep dari kesiapan untuk sekolah adalah termasuk didalamnya kesiapan untuk belajar didasarkan pada standar tingkat perkembangan fisik, kognitif dan sosial yang memungkinkan anak untuk memenuhi tuntutan dan menjalani kurikulum yang telah ditentukan.

Tes menggunakan Nijmeegse Schoolbekwaamheids Test (NST) memperlihatkan kematangan aspek-aspek yang menunjang kesiapan anak masuk Sekolah Dasar. Sebagaimana ditunjukkan dalam hasil yang diperoleh siswa bahwa dari 10 aspek, 7 aspek bisa dikatakan tingkat kematangannya cukup optimal sedangkan 3 aspek yaitu motorik halus, pengertian objek dan penilaian sosial, serta gambar orang tingkat kematangannya banyak yang belum optimal. Sebagaimana dijelaskan dalam Supartini (2006) bahwa rangkaian subtes NST terdiri dari : I. Pengamatan bentuk dan kemampuan membedakan; 2. Motorik halus; 3. Pengertian tentang besar, jumlah, dan perbandingan; 4. Pengamatan tajam; 5. Kemampuan berpikir kritis; 6. Konsentrasi; 7. Ingatan; 8. Pengertian objek dan penilaian situasi; 9. Menirukan cerita; 10. Menggambar orang. 
Jika dicermati aspek-aspek yang tingkat kematangannya sudah optimal adalah aspek-aspek yang terkait dengan kemampuan kognitif dan motorik, sedangkan aspek yang tingkat kematangannya belum optimal terkait dengan aspek sosial dan emosi. Aspek yang tingkat kematangannya belum optimal adalah aspek 10 yakni menggambar orang. Masih banyak yang belum memiliki kesadaran akan bagian tubuhnya. Hal ini menunjukkan bahwa ia tidak terlatih untuk menggunakan bagian tubuhnya sehingga harus diberikan berbagai kegiatan yang melibatkan anggota tubuh agar body imagenya meningkat.

Selanjutnya aspek 8 pengertian tentang objek dan penilaian terhadap situasi sosial. Perkembangan sosial-emosi anak usia prasekolah ditandai dengan perkembangan anak dalam mengerti perasaan dan belajar mengembangkan hubungan interpersonal yang efektif. Kesulitan dalam adaptasi dan sosialisasi.

Sebagaimana diungkapkan oleh Rachmawati dan Damayanti (2016) bahwa kematangan pada aspek emosi dan sosial memungkinkan anak untuk secara nyaman 'terpisah' dari lingkungan rumah, terutama orang tua, dan mulai memperluas lingkup sosial pada konteks pertemanan, baik dengan sebaya, dan juga dengan orang dewasa lain, dalam hal ini guru. Kondisi ini juga menjadi dasar untuk mencapai kemandirian dalam penyelesaian tugas. Bahkan lebih lanjut lagi dapat memungkinkan anak untuk menjadi individu yang berani tampil dan mampu secara asertif menyatakan pendapat. Kematangan pada aspek ini juga memungkinkan anak untuk mengembangkan kepekaan dan rasa kebersamaan dengan orang lain.

Aspek yang telah berkembang dengan optimal diantaranya motorik halus dan kemampuan kognitif. Namun demikian kemampuan ini masih perlu peningkatakatan melihat masih ada beberapa siswa yang belum mencapai kesiapan secara optimal. Hal ini yang akan menyulitkan kemampuan anak dalam mengikuti proses belajar mengajar di Sekolah Dasar. Tuntutan akademis di SD untuk melakukan kegiatan tulis-menulis membutuhkan ketrampilan motorik halus. Diperlukan latihan untuk melemaskan jari-jari misalnya dengan mewarnai, meronce, menggunting, menempel, bermain lilin dsb.

Hal ini sebagaimana diungkapkan oleh Hurlock (Sulistiyaningsih, 2005) yang menyatakan bahwa kesiapan bersekolah terdiri dari kesiapan secara fisik dan psikologis, yang meliputi kesiapan emosi, sosial dan intelektual. Seorang anak dikatakan telah memiliki kesiapan fisik bila perkembangan motoriknya 
sudah matang, terutama koordinasi antara mata dengan tangan (visio motorik) berkembang baik.

\section{SIMPULAN}

Dari hasil penelitian kesiapan masuk sekolah dasar siswa TKIT Attaqwa Gumawang dapat disimpulkan bahwa seluruh aspek yang diperlukan untuk kesiapan siswa masuk Sekolah Dasar pada umumnya sudah matang. Secara kualitatif, aspek kesiapan masuk Sekolah dasar yang terkait dengan aspek kognitif yaitu pengamatan dan kemampuan membedakan, pengertian tentang besar, jumlah dan perbandingan, ketajaman pengamatan, pengamatan kritis, konsentrasi, motorik halus dan memahami cerita adalah aspek-aspek yang sudah mencapai tingkat kematangan yang cukup optimal. Sedangkan aspek yang terkait dengan kemampuan aspek daya ingat, aspek penilaian terhadap situasi dan gambar orang tingkat kematangannya belum optimal.

Setelah diperoleh hasil penelitian kesiapan masuk sekolah dasar siswa TKIT Attaqwa Gumawang, maka saran yang diberikan oleh peneliti adalah perlunya pengkajian lebih lanjut tentang kesiapan masuk sekolah yang dikaitkan dengan faktor lain, misalnya pola asuh atapun kompetensi guru. Memberikan stimulasi yang seimbang pada berbagai aspek perkembangan anak agar kematangannya optimal. Kegiatan belajar tidak hanya menekankan stimulasi yang sifatnya latihan semata, tetapi aspek lain perlu diperhatikan mengingat perkembangan yang optimal hanya dapat dicapai apabila seluruh aspek perkembangan terstimulasi dengan baik.

\section{REFERENSI}

Ambarwati, T. (2016). Tes Kesiapan Masuk Sekolah Dasar. [Online]. Tersedia: http://www.biropsikologi.info/tes-kesiapan-masuk-sekolah-dasar.html. [22 Januari 2016].

Damayanti, A. K., \& Rachmawati, R. (2016). Kesiapan Anak Masuk Sekolah Dasar Ditinjau Dari Dukungan Orang Tua dan Motivasi Belajar. PSIKOVIDYA, 20(I), 16-25.

Jannah, M. (20I5). Menakar Kesiapan Anak Masuk Sekolah. [Online]. Tersedia: http://www.mj-ariseno.blogspot.com/2015/02/menakar-kesiapan-anakmasuk-sekolah.html?m= I. [22 Januari 20l6]. 
Kustimah, Abidin, F. A., \& Kusumawati, D. (2016). Gambaran Kesiapan Anak Masuk Sekolah Dasar Ditinjau Dari Hasil Tes Nst (Nijmeegse Schoolbekwaamheids Test). [Online]. Tersedia: http://repository.unpad.ac.id/2937/I/gambaran_kesiapan_anak_masuk_s ekolah_dasar.pdf. [15 Desember 2016].

Sandriana, E. (20I5). Kematangan Sekolah. [Online]. Tersedia: http://www.m.kompasiana.com/eva_sadrina/kematangan-kesiapansekolah-ayo-cek-dulu_553785726ea834f35da42d0. [22 Januari 20 I6].

Sudjana. (1994). Metoda Statistika. Bandung: Tarsito

Sulistiyaningsih, W. (2005). Kesiapan Bersekolah Anak Ditinjau Dari Jenis Pendidikan Pra Sekolah Anak dan Tingkat Pendidikan Orangtua. Jurnal Psikologia, I(I).

Supartini, E. (2006). Pengukuran Kesiapan Sekolah. Jurnal Pendidikan Khusus, 2(2).

Suryabrata, S. (1994). Metodologi Penelitian. Jakarta: Raja Garafindo Persada.

Yusuf, S. L. N., \& Sugandhi, N. M. (20I2). Perkembangan Peserta Didik. Jakarta: Rajawali Pers. 